\title{
FLEECING THE MALE CUSTOMER IN SHANGHAI BROTHELS OF THE 1890s
}

\author{
Keith McMahon
}

Late Qing novels abound in situations of transition, where classical antecedents coexist with modern departures. In this period of not-so-sure adjustment, we still encounter the love fantasy of the elite prostitute and her male patron, which has traditionally constituted a home away from the ritually defined home of marriage and family. In the 1892 novel Flowers of Shanghai (Haishanghua liezhuan), by Han Bangqing, this home away from home has now moved to the separate space of the foreign concessions of Shanghai, which is, in effect, a city away from the rest-of-China. ${ }^{1}$ There, where capitalism and foreign laws reign, the role of the traditional master-Confucian father, local magistrate, or the emperor himself - has weakened. Instead we have the vigorous and entrepreneurial prostitute and her male patron, the man whom she "fleeces" (qiao) as he searches for the woman with the most aura. It is the particular way Han Bangqing portrays this prostitute that makes the novel so singular. He begins by vilifying her in a manner that is common to other writings of the period, ${ }^{2}$ namely, that she wears beauty on the outside but is poisonous within, "The one before your eyes may be as beautiful as the legendary Xishi, but underneath she is more vicious than a yaksha" (1.1). Yet Flowers of Shanghai then quietly brackets that viewpoint as one belonging to the stymied male and instead goes on to foreground the reality of the business of the brothel, that is, the womens' often urgent problems of getting by, about which

\footnotetext{
$1 \quad$ Flowers of Shanghai is remarkable among late Qing novels in that all ance it embodies several levels of paradigmatic change: its author, a professional writer who, although a xiucai, has abandoned the pursuits of the literatus-scholar; its chapter formation, which reflects the conditions of journalistic serialization; its setting, the Shanghai of the foreign concessions; and its characterization, which will be my focus in this paper. For details on the connection between changes in narrative style and serialization (which had already occurred with Gulliver's Travels and "Rip Van Winkle" in Shenbao in 1872 and 1873 and which also has to do with developments in the printing industry) and the professionalization of writers, see Chen Bohai and Yuan Jin, Shanghai jindai wenxueshi [History of modern Shanghai literature] (Shanghai: Shanghai renmin chubanshe, 1993), 238-39, 241. The edition I use is: Han Bangqing, Haishanghua liezhuan (Haikou: Hainan chubanshe, 1997).

2 See, for example, the 1903 Haishang fanhuameng [Shanghai splendor], and the 1910 Jiuweigui [Ninetailed turtle].
}

Late Imperial China Vol. 23, No. 2 (December 2002): 1-32

(C) by the Society for Qing Studies 
male patrons are ignorant or cynical. The author features the prostitute's aptitude at adapting to the constantly shifting conditions of business in the foreign concessions of Shanghai. At the same time, he demonstrates that it is the foolishness of men which is one of the prostitute's greatest assets.

What I would like to do in this essay is first to evaluate the newness of Shanghai as it is fictionally presented, and then to juxtapose this portrayal with the description of the peculiar powers that the novel's "prostitute-yakshas" exercise over their male clients. My main theme will be to demonstrate how the male customer seeks self-definition through his relationship with the prostitute, and how he in fact finds pleasure in the aura of control that the prostitute exerts over him. What are then the particular elements of the prostituteyaksha's aura? If, in other words, she is the entrepreneur at the forefront of change in the new city of Shanghai, then what actually constitutes her ability to do business? In Han Bangqing's portrayal, it is the appearance of control that the woman exerts over the man that determines how successful a prostitute she is. But such control has to be understood not merely in the obvious sense that the most successful prostitute is the one who can compel her customer to find yet more reasons to spend money in her brothel. Instead, to put it in terms of a kernel formula, the most successful prostitute is the one who constantly stays beyond the man's grasp, yet keeps him wanting to achieve that grasp. This elusive woman somehow understands and makes a living on the idea that the man defines himself through a certain image he has of her, and she therefore strives to become the one who perfectly fits that man's particular image. In the most general sense, she succeeds in doing so by making herself "unabandonable," that is, by becoming someone the man cannot bear to leave.

What, however, is so different about this otherwise rather commonly known situation in Chinese literature of a man's fascination with a prostitute? Flowers of Shanghai occupies a significant position in the history of Qing fiction by offering a crystallized portrait of historical transition in the late Qing, especially in terms of the relationship between courtesan and patron. My method of laying open this transition will be to focus on Flowers of Shanghai both in light of its antecedents from the Ming through the Qing and then as its own profound departure from them. Something about the city of Shanghai, as Han Bangqing and other authors conjure it, calls into being a new set of male and female roles in which the male customer who enters the Shanghai brothel must learn what amounts to a new vocabulary of love. He is at a loss unless he realizes that the prostitutes have adjusted to Shanghai more swiftly than he. These women somewhat recall the cainü, "female genius" or "talented woman," whether courtesan or gentry woman, who first made themselves famous as literary talents and heroic loyalists at the end of the Ming. In Flowers of Shang- 
hai they are minus their literary talents and their heroic loyalism, but are still remarkable for their independence and fortitude, and now also their newly developed tactics of "doing business," zuo shengyi, as they often intone. The key words used throughout Flowers of Shanghai to signal such women are benshi, "talent," and zhengqi, "to make good for herself" or, more literally, "to get her air." That is, the woman who has "talent" is the one who succeeds at the business of prostitution by amassing wealth and respect. Such a woman "makes good for herself" because of her exceptional capability in getting men to follow her wishes. She is the subject of comments by other prostitutes who admire or wonder at her and often resent her, but who consider her an exemplar of a successful prostitute.

The emphasis on the newness of the era that Han Bangqing presents can be seen at the very beginning of Flowers of Shanghai, which commences precisely at a bridge in Shanghai where "China" (hua) meets the "West" (yang, 1.2). The time frame, moreover, is that of "since Shanghai linked its commerce with the outside" (haishang zi tongshang yilai, 1.1). Ever since that beginning, the narrator continues, prostitution has burgeoned and wastrels (yeyou zidi) have poured into Shanghai. The reference to this beginning is as if to announce that a new kind of wastrel has arrived, freshly unsprung and ready to throw everything aside, that is, the China of his origins. The foreign concessions of Shanghai represent an untrodden place to go to be larger-thanlife in any way that business or other pursuits will allow. There the wastrel is ready to go both to cheat and be cheated, but mostly be cheated, and thus this book: to represent the "one who has seen it all" (guolairen) and to teach the wastrel not by admonishment but by "the method of real-life presentation" (xianshen shuofa, 1.1). As formulaic as these lines may be for the start of a Qing novel, the situation in the time and place of Shanghai implicitly creates a fresh wastrel who has to be told all over again, so to speak, how to survive in the world of fleshly effects.

My first task will be that of placing Flowers of Shanghai in its historical context. This necessitates listing some of the well-known features of the foreign concessions of Shanghai that recent scholars have outlined, but also requires that we keep the Ming and Qing past in mind, in order that we may better understand the status of love in the new world of the Shanghai brothel. I will then deal with my two main topics: the elite prostitute and her control of the man, that is, the control he appears to seek in her and through which she thereby makes herself unabandonable; and then the character Hong Shanqing as the example of a new male hero in the Chinese novel, one who is neither nostalgic about the pre-Shanghai past nor bitterly victimized by the Shanghai present. 
First, however, since the novel is still not very well known, we must provide a summary of it and a short introduction of the author Han Bangqing. Flowers of Shanghai consists of numerous strands, the central of which is the story of Zhao Puzhai, his sister Zhao Erbao, and their uncle Hong Shanqing. ${ }^{3}$ Zhao Puzhai travels to Shanghai hoping his uncle will find him work there, but first wants to visit prostitutes, for which he has heard Shanghai is famous. Hong Shanqing takes him to a high-class brothel where Zhao meets a woman who later fleeces him, leaving Zhao without means to escape Shanghai and go home. Hong Shanqing tries to rescue him several times but to no avail. Finally, Zhao's mother and sister, Zhao Erbao, come looking for him and find him in rags. Meanwhile, Zhao Erbao becomes so enamored of Shanghai life that she likewise spends all her money and has to become a prostitute. She meets a wealthy man, Shi San Gongzi (i.e., Shi Tianran), who promises to marry her and helps support her and Zhao Puzhai. But he disappears, she is forced to take customers again, and at the end of the novel is threatened by a hooligan who wrecks her apartments (ch. 64). Numerous other characters appear throughout, with Hong Shanqing serving as a kind of mediator and facilitator for prostitutes and patrons who run into problems, such as the older patron Wang Liansheng who betrays the prostitute Shen Xiaohong, whom he in turn discovers has been cheating on him; or the young man Zhu Shuren and the prostitute Zhou Shuangyu, who fall too much in love in spite of the conventions of the brothel business which discourage such love. Hong Shanqing, in fact, is the unsung hero of Flowers of Shanghai, not brilliant, virtuous, or valiant, but nevertheless representative of a kind of new man who, as I have said, neither longs for the past nor feels incapacitated or overly fascinated by the glittering but unstable present.

\section{The Author and his Shanghai Milieu}

The first twenty-eight chapters of Flowers of Shanghai appeared in serial form in 1892 in a bi-weekly magazine founded by the author, Han Bangqing (1856-94). ${ }^{4}$ He stands apart from traditional authors of vernacular fiction because he is among the numerous professional writers who came into being

\footnotetext{
3 The existence of these numerous strands, which constantly intermingle, is in great part due to the serialized nature of the novel's initial publication. Such serialization had been seen before in translations of foreign novels, but Flowers of Shanghai was the first Chinese novel to be published in such a way. See Chen Bohai and Yuan Jin, Shanghai jindai wenxueshi, 239.

4 This fact is remarkable because of the relative novelty of the literary magazine, many more of which would come into existence in the next ten years. The novel was published in book form in 1894. See Chen Bohai and Yuan Jin, Shanghai jindai wenxueshi, 235, 239, and David Der-wei Wang, Fin-de-siècle Splendor: Repressed Modernities of Late Qing Fiction, 1849-1911 (Stanford: Stanford University Press, 1997), 89 and 360, n. 80. Flowers of Shanghai can also be translated as Singsong Girls of Shanghai or Biographies of Shanghai Flowers, where "flowers" stands for prostitutes.
} 
as a result of the formation of the foreign concessions in Shanghai. ${ }^{5}$ Their association with newspapers or with the work of translation between Western languages and Chinese sets them apart from the literatus-scholar whose life centers on the curriculum of classical learning in preparation for service in the imperial bureaucracy. ${ }^{6}$ Many such individuals abandoned that career to try their luck in the new world of professional writing that was made possible in Shanghai. Han Bangqing predates by only half a decade or so the explosion of professional writing of fiction that takes place with authors such as Li Boyuan, Wu Jianren, and Zhang Chunfan. His source of income is not altogether clear, but at least in part came from his contributions to the Shanghai newspaper Shenbao. ${ }^{7}$ He kept company with other literate friends who together wrote poetry and also, we might infer, together enjoyed the company of prostitutes and smoked opium. He was known to be an opium smoker himself and supposedly lived with his mistress-courtesan in her chambers. ${ }^{8}$

Writing about prostitution was in itself a pursuit which had existed for centuries, and continued voluminously in Shanghai. ${ }^{9}$ Flowers of Shanghai marks a significant departure because of both its lengthy novel form and its focus on Shanghai. It is the first novel on prostitution in Shanghai. Many other authors wrote biographies, articles, essays, and guidebooks about pros-

\footnotetext{
Preceding Han are figures like Wang Tao (James Legge's assistant in the translation of the Chinese classics), Qian Zheng, and Cai Erkang. On Wang Tao and three other writers similar to the ones named here, see Catherine Yeh, "The Life-style of Four Wenren in Late Qing Shanghai," Harvard Journal of Asiatic Studies 57.2 (1997): 419-470. Scores of other writers, including non-professional ones, lived in or around Shanghai or spent significant periods of time there, e.g., the poet and diplomat Huang Zunxian (1848-1905), the poet and educator Liu Xizai (1813-81), the poet and painter Yao Xie (1805-64), and dramatists including Li Ciming (1829-94) and Xu E (1844-1903). A large body of "bamboo-twig lyrics" (zhuzhici) also exists from the period which centers on life in Shanghai, its customs, character types, and material culture. See Gu Bingquan, Shanghai yangchang zhuzhici (Shanghai: Shanghai guji chubanshe, 1996).

6 To be sure, these men were classically educated. Han himself, a xiucai who repeatedly failed the provincial exams, served in that bureaucracy in a low ranking capacity before settling in Shanghai.

Shenbao began in 1872 . Other such literary venues existed and many more would soon come into being, especially after 1895 .

8 He was not the only writer to smoke opium. As Yeh notes, the novelist Zeng Pu was an addict who, according to Bao Tianxiao, wrote Niehai hua [Flowers in the bitter sea] while continuing his opium habit ("The Life-style of Four Wenren," 455). According to Liu Bannong and Hu Shi, Han Bangqing reportedly spent his inherited wealth in the brothels of Shanghai; Liu Bannong, "Du Haishanghua liezhuan," in Han Bangqing, Haishanghua liezhuan, 28; and Hu Shi, "Hu Shi xu," in Han Bangqing, Haishanghua liezhuan, $1-18$.

9 On eighteenth and nineteenth-century biographies of courtesans, see Susan Mann, Precious Records: Women in China 's Long Eighteenth Century (Stanford: Stanford University Press, 1997). On writings about prostitutes in Shanghai, see Christian Henriot, Belles de Shanghai: Prostitution et sexualité en Chine aux XIXe-XXe siècles (Paris: CNRS Editions, 1997), 33ff. For the period after about 1895, see sources used by Henriot, Belles de Shanghai, and Gail Hershatter, Dangerous Pleasures: Prostitution and Modernity in Twentieth-Century Shanghai (Berkeley: University of California Press, 1997). For more on Wang Tao and his involvement with and writing about courtesans, see Yeh, "The Life-style of Four Wenren," 428-34.
} 
titution before and to a greater extent after Han Bangqing. Works of fiction about prostitution in Shanghai grew in number especially starting in the late 1890s. Han's novel was not generally popular, as David Wang notes, but instead had to rely on twentieth-century writers such as Lu Xun, Hu Shih, and Zhang Ailing (Eileen Zhang) to give it a prominent place. ${ }^{10}$ Han's cool observation of brothel life and the complex and constant interweaving of separate lines of plot perhaps did not lend well to popular reading. ${ }^{11}$ It is this coolness, however, that explains his toying with hackneyed formulas and that makes him a good translator of the particular newness of the city of Shanghai.

This newness has been detailed by other scholars, but merits a brief summary here. The novel's departures from its literary past, in fact, gain much of their weight from the singular nature of the city of Shanghai. ${ }^{12}$ The foreign concessions of Shanghai were established as a result of the Nanjing Treaty of 1842 and were legally distinct from the rest of China. The city ran according to Western law and Western calendar, that is, the seven-day week with Sunday as a day of rest, an arrangement that the rest of China (except for other concessions) did not adopt until later. The effects of this environment on brothels in particular can be seen in terms of both a newfound security to do business and freedom from Chinese authority. ${ }^{13}$ Western-style buildings, straight and wide roads, and things such as steamships and eventually electricity, photography, and telephones, all conjoined to provide men and women with novel

\footnotetext{
10 See Wang, Fin-de-siècle Splendor, 89-101. Yuan Jin considers it the best novel of the jindai period (Chen Bohai and Yuan Jin, Shanghai jindai wenxueshi, 236). Zhang Ailing's translation of the Wu dialect passages into Mandarin has made the book more widely readable, but eliminates four chapters. See Zhang Ailing, trans., Haishanghua (Taibei: Huangguan chubanshe, 1983); thanks to Ted Huters for providing me with this edition. The edition I use is a 1997 reprint of Hu Shi's Yadong Library edition of 1926 (see footnote 1). The advantage of this edition is its inclusion of a Mandarin translation beside the passages in $\mathrm{Wu}$ dialect. I have also made use of the $\mathrm{Wu}$ dialect dictionary compiled by $\mathrm{Wu}$ Liansheng et al., $\mathrm{Wu}$ fangyan cidian [Dictionary of the Wu dialect] (Beijing: Hanyu da cidian chubanshe, 1995). In all my romanizations, however, I have transcribed the Wu dialect into Mandarin pinyin due to my lack of competence in the $\mathrm{Wu}$ sound system.

1 See Hu, "Hu Shi xu," 17, and Liu, "Du Haishanghua liezhuan," 27.

12 See Wang, Fin-de-siècle Splendor, 89-90, 99. Yeh also notes many of the transformations that have occurred in late Qing Shanghai, especially as concentrated in the world of the brothel. See Catherine Yeh, "Reinventing Ritual: Late Qing Handbooks for Proper Customer Behavior in Shanghai Courtesan Houses," Late Imperial China 19.2 (1998): 1-63. In addition, see Yeh's "The Life-style of Four Wenren" and "Cong shijiu shiji Shanghai ditu kan dui chengshi weilai dingyi de zhengduozhan" [Nineteenth-century maps and the debate over the future shape of Shanghai], Zhongguo xиeshu 1.3 (2000): 88-121.

13 Around the 1860 s, the main locale of the business of prostitution began moving out of the walled Chinese city of Shanghai over to the foreign concessions. It is said that one of the main reasons was the instability caused by the Taiping Rebellion in surrounding regions, from which numerous people sought refuge in Shanghai (Henriot, Belles de Shanghai, chapter 8, and Yeh, "Reinventing Ritual," 5). As Yeh notes, courtesans gained a new sense of power in the setting of the Shanghai foreign concessions. See "Reinventing Ritual," 2-3. See also Hershatter, who is somewhat more cautious than Yeh in making the same point (Dangerous Pleasures, 73, 125).
} 
and appealing forms of entertainment and opportunities for moving about in unprecedented ways and at all hours of day and night (Han Bangqing shows this especially in his story of Zhao Erbao and her brother Zhao Puzhai). ${ }^{14}$ Men and women mingled in settings such as tea and coffee houses, restaurants, and public parks, and drove in open carriages and later automobiles as they went on outings for pleasure. ${ }^{15}$ In the terms that fictional portrayals often employed, the new environment of Shanghai also amounted to a giant trap in which no one could be trusted. As the stories went, people from a young woman's home village would earn money by tricking her into prostitution in Shanghai. Parents would sell their daughters into brothels; husbands would sell their wives. In the most general sense, Shanghai was a place where thingsrelationships in particular - were no longer the same, which specifically meant that nothing was as stable and reliable as before. ${ }^{16}$

\section{Ming and Qing Literary Antecedents}

At this volatile late Qing juncture, Flowers of Shanghai bears numerous resemblances to works by male literati of the late Ming and the Qing that extolled "talented women." These cainü of the Ming and Qing, among whom courtesans were numerous, were admired because of their literary and artistic talents, and at the fall of the Ming also because of their numerous instances of moral heroism and loyalism. By the 1890s literary talent in the courtesan had become a relic of little authenticity, and is even the subject of satire in Flowers of Shanghai. ${ }^{17}$ Nevertheless, the courtesan-literatus relationship that was prominent in China for already hundreds of years still informs the 1892 Flowers of Shanghai as a guiding memory. Most of the prostitutes in Flowers of Shanghai may still be thought of as courtesans in the sense that the high-class

14 Novels sometimes refer to the differences between old and new Shanghai. The 1897 Haishang chentianying, or Shadows of Shanghai Dust, by Zou Tao (1850-1931), for example, contains a derogatory reference to the dirty, cramped old city of Shanghai; Zou Tao, Haishang chentianying (Nanchang: Baihuazhou wenyi chubanshe: 1993), 10.137.

15 Officials in the Chinese city of Shanghai were not happy with the movement of prostitution to the concessions. In 1870, a daotai (circuit intendant) even tried to order the closure of all brothels there, where he had no real jurisdiction (Henriot, Belles de Shanghai, 315, and Yeh, "Reinventing Ritual," 6-7). In the 1880 s, officials again tried to control this freedom of movement among prostitutes, issuing orders (likewise ineffective) that no women be employed in teahouses (Henriot, Belles de Shanghai, 316).

16 My understanding of this milieu has benefited immensely from two major studies of prostitution in Shanghai in the nineteenth and twentieth centuries, Gail Hershatter's Dangerous Pleasures and Christian Henriot's Belles de Shanghai. I have also found especially helpful Chen Bohai and Yuan Jin, Shanghai jindai wenxueshi, Yeh, "The Life-style of Four Wenren," and "Reinventing Ritual," and Paola Zamperini, "But I Never Learned to Waltz: The 'Real' and Imagined Education of a Courtesan in the Late Qing," Nan Nü 1.1 (1999): 107-44, and "Lost Bodies: Images and Representations of Prostitution in Late Qing Fiction" (Ph.D. diss., University of California at Berkeley, 1999).

17 See the character discussed below, Wen Junyu. 
ones (called shuyu or changsan, and yao'ni if they are slightly lower) live in well-furbished brothels, are commonly adept at some kind of musical performance, and if possible like to form steady relationships with one man at a time. The men are well-to-do merchants and officials, some are gamblers and even gangsters, while others are neither employed as merchants nor officials but are otherwise well-off or highly educated. In general, however, the women can no longer write poetry or classical prose, and neither can many of the men. ${ }^{18}$ But at certain gatherings, especially those in the palatial compound of an elderly rich man (Qi Yunsou), the men attempt to carry on in the tradition of literary drinking games, and they sometimes lament that they can now only rarely find talented courtesans. ${ }^{19}$

My point is that whatever aspects of the former courtesan have been lost, patterns and precedents remain which take on character in Flowers of Shanghai and other works only if we keep the Ming and Qing past in mind. ${ }^{20}$ The models established or reinforced in these earlier times were a fixed part of the courtesan/client relationship thereafter. The late Qing novel presents the perception that prostitution had become shamelessly commercialized, and that a patron could hardly hope to find an old-fashioned courtesan. But certain motifs in the form of modes of behavior still remain. These include things such as the expression of sympathy for the unfortunate woman (as seen in numerous novels when male customers ask for details about how the woman became a prostitute) ${ }^{21}$ or the woman's refusal to cooperate with the man and

\footnotetext{
18 E.g., Chen Xiaoyun and Luo Zifu (for the latter, see 59.508).

19 Zhang Ailing deletes these portions of the novel. That courtesans were less and less literate is also recorded by Wang Tao and others (Henriot, Belles de Shanghai, 40-41, and Hershatter, Dangerous Pleasures, 42). Still, as Yeh notes, famous writers and reformers in the 1890s frequently socialized in courtesan houses ("The Life-style of Four Wenren," 449, 456). Zou Tao's 1897 Shadows of Shanghai Dust still adheres to the model of the highly talented courtesan.

20 The courtesan-literatus relationship achieved singular height in the late Ming in numerous literary formats in which the woman was set off as if she were a sublime being; see Katherine Carlitz, "Desire and Writing in the Late Ming Play Parrot Island," in Ellen Widmer and Kang-i Sun Chang, eds., Writing Women in Late Imperial China (Stanford: Stanford University Press, 1997), 101-130, especially 106, 109; and Li Wai-yee, "The Late Ming Courtesan: Invention of a Cultural Ideal," in Widmer and Chang, eds., 46-73, and "Heroic Transformations: Women and National Trauma in Early Qing Literature," HJAS 59.2 (1999): 363-443. She was highly eroticized but at the same time placed beyond the realm of vulgar sensuality. Poetry and prose both by and about these women were anthologized in collections from the late Ming through the Qing (Kang-i Sun Chang, "Ming and Qing Anthologies of Women's Poetry and Their Selection Strategies," in Widmer and Chang, eds., 147-170). The women were idealized for their embodiment of personal independence and their exercise of self-definition, despite the stigma of their social status ( $\mathrm{Li}$ Wai-yee, "The Late Ming Courtesan," 53). Self-definition included the way they designed their abodes, which came to represent retreats from male social and political circles and which thereby offered a sense of purification and release ( $\mathrm{Li}$, "The Late Ming Courtesan," 72). Male writing about courtesans was also a forum for the expression of nostalgia for the treasured times before the fall of the Ming, as seen especially in Yu Huai's (1616-96) Banqiao zaji [Miscellaneous records of the wooden bridge].

${ }_{21}$ See, for example, Li Shifu and the prostitute Zhu Shiquan.
} 
her ability to make him do as she wishes. ${ }^{22}$ Such willfulness also includes her taking the initiative in proposing or resisting a relationship. ${ }^{23}$ In Flowers of Shanghai these modes of behavior - or their pretentious imitations - constitute markers by which prostitutes and their customers might try to divide themselves off from supposedly inferior competition.

A rich corpus of erotic literature also precedes the late Qing novel about courtesans. If Flowers of Shanghai could be taken as a commentary on these works, it would be as if saying that the ease and success with which the former sexual hero enjoyed seducing one woman after another was too fantastic. Stories that are too fantastic ignore the fact that men have to stand many more tests before even being allowed into the bed of a woman he pays to have sex with. The successful polygamist of earlier erotic romances appears in Flowers of Shanghai in the form of highly respected men of wealth who have multiple wives and few worries. ${ }^{24}$ But the novel hardly alludes to the polygamist in his aspect as potent sexual master. In general, sex in Flowers of Shanghai occurs offstage: it is something overheard in another room (26.224) or it happens after the man and women finally get in bed, with the narrator providing no details. ${ }^{25}$

The most direct statement of this limited opening onto sex is found in the repeated portrayal of men who frequent cheaper, lower-ranking prostitutes whom they meet in opium dens and brothels in the French Concession. The

22 In the late Ming this behavior appears, for example, when a famous courtesan poet scolds her lover (perhaps fictitious) for his absence and disloyalty (Paul Ropp, “Ambiguous Images of Courtesan Culture in Late Imperial China," in Widmer and Chang, eds., 17-45, see 22); when women reject rich but grotesque customers for the sake of kinder or handsomer but poorer ones; or when women redeem themselves from their owners but remain courtesans or when they marry but later return to their former career in which they then become a focus of male attention and respect. See, for example, Yu Huai, trans. Howard Levy, $A$ Feast of Mist and Flowers [Banqiao zaji] (Yokohama: mimeographed, 1966), 81.

23 Several such examples were recorded in the late Ming, one of the most famous of which is a story about Liu Rushi (see Li, "The Late Ming Courtesan," 59). She tests a certain man's loyalty by having him jump into water in cold weather. She then takes him indoors and warms him in bed with her body. At a later time, after they become more involved, she breaks with him when he hesitates after she indirectly proposes to him. See Li, 58-59, and Chen Yinke, Liu Rushi biezhuan [The other story of Liu Rushi] (Shanghai: Shanghai guji chubanshe, 1980), 69. See also the famous story of Wu Weiye and Bian Yujing as discussed in Li, "Heroic Transformations," 412-13, and in Wu Weiye, Meicun jiacangji [The collected poems of Wu Weiye] (Shanghai: Shangwu yinshu guan, 1922), juan10.2b-3a.

24 Like Li Zhuanhong (14.118) and the elder Qi Yunsou (ch. 26). But the author does not fail to include remarks and observations that women make regarding their lack of love for Qi Yunsou or, for example, how "horrid" he looks when asleep with his eyes partly open (51.437). They also assert that, as benevolent as he is, he can never know what is "in their hearts."

25 The single passage of erotic description at the beginning of Chapter Fifty-one occurs as a citation of an erotic set piece. Accordingly, it is written in highly allusive classical language, in contrast to the rest of the novel in which the narrative is in vernacular Mandarin and the dialogue in Wu dialect. In this passage, a young scholar easily prevails over the women with whom he joins in sexual battle, just like the sexual hero of the erotic romances. 
expectation in visiting these prostitutes is that sex is more readily available and that the relation between money paid and sex enjoyed is more direct than in higher-class brothels. One man (Li Shifu) contracts venereal disease from a woman he thinks is another man's wife, while the chief stewards of many of the men (including Li Shifu's) frequent the cheapest prostitutes whose quarters are filled with one customer after another, each interrupting or crowding out the last (these are the "Flower and Opium Rooms"- huayanjian - where the prostitutes Pan San and Wang A'er live ${ }^{26}$ ). Cheap and diseased sex thus contrasts with the sublime experience portrayed in the high erotic and with the robust promiscuity of the Qing erotic romance. Sex in Flowers of Shanghai is largely out of the picture, as I have said, even though it is a supposed primary reason for which the prostitute is there, and for which men converge on Shanghai to find them. Social relations and transactions surrounding or happening instead of sexual relations are the main objects of portrayal.

\section{The Status of Love and "Doing Business"}

Given the tradition of the sublime relationship between courtesan and scholar, what is the status of love among the Shanghai descendants of that tradition? In Flowers of Shanghai it is as if all illusions of love are barred in the new world of the foreign concessions. There everything is business, shengyi, and everyone is a possible cheat, even someone "from your own home village" (as Hong Shanqing says to the naif Zhao Puzhai, 12.101-02 and 13.105). The rule about love as stated at least twice in Flowers of Shanghai is that the deeper the feelings are between man and prostitute, the more trouble there will be for them. "The closer you are to your mistress, the less long-lasting your affair will be," or, "The closer you are, the more trouble you get yourself into," both said about the couple Tao Yufu and the prostitute Lin Shufang $(7.58 ; 42.354)$. In this and another case, man and woman fall in love before elders and managers can prevent it. ${ }^{27}$ Lin Shufang is dying of tuberculosis; Tao takes care of her until her death. She is said to be grieving because she knows she can never become Tao's main wife due to his family's disapproval of his marriage to a prostitute. After she dies, he suffers uncontrollable grief which he displays publicly except when his elder brother manages to remove him from situations which stir him too deeply. Tao Yufu is young and inexperienced, that is, not yet wise to the world in contrast to his elder brother and even Lin Shufang herself, who nevertheless still struggles angrily against

\footnotetext{
26 "Flower and smoke brothels" (huayanjian) were grouped near the "Bridge of the Beaten Dog" (dagouqiao) in the French Concession (Hershatter, Dangerous Pleasures, 49; Henriot, Belles de Shanghai, 244). 27 At the same time, one prostitute admires the intensity of the affair between Tao and Lin, especially given that Shanghai is a place in which there is so much "deception" (pian, 36.305).
} 
impossible odds. In the eyes of the elder brother and Hong Shanqing, prostitute and client should not take each other too seriously. Everyone should know that Shanghai is full of traps, and that prostitutes and customers are only playing when they voice commitments of devotion and love. Love is not a gift that anyone is presumed to have, although it sometimes breaks out anyway.

The sense that works like Flowers of Shanghai repeatedly evoke is that the reason Shanghai has become this way is that a major change has occurred in the use and flow of money. In the world of brothels in particular, money appears to have acquired a magic capacity to turn things into their opposites. What is repulsive becomes attractive; what is low becomes high; what is lofty is rendered useless. For example, a so-called "ugly" but famous prostitute (that is, Tu Mingzhu) can command more money than a good-looking prostitute or an inexperienced virgin (for whom the special term was qingguanren). The nouveau riche, half-educated man (such as Chen Xiaoyun and other merchants in Flowers of Shanghai) can become a customer of a high-class brothel just by showing he can spend money. In short, an object of mere monetary value is endowed with the power of levelling formerly unequivalent things and re-assigning their value.

The foregrounding of money in this and other novels is most apparent in the prostitute's explicit reference to "doing business," words which are absent in slightly earlier novels about courtesans, like Huayuehen [Trace of moon and flowers] and Qingloumeng [Dream of the green chamber], in which the mention of "business" would be the height of vulgarity. ${ }^{28}$ The story of the poet-courtesan Wen Junyu illustrates the satirical way in which Han Bangqing captures the prostitute's position at the forefront of this change. The opiumaddicted Wen Junyu likes to assert that there are no true prostitutes in the Shanghai concessions, that is, ones who know classical literature as they did in earlier times (56.482) ${ }^{29}$ However, although she has admirers among the

28 As Yeh notes, "The changsan were not shy about the professional aspect of their life, referring to their entertaining clients as 'doing business,' zuo shengyi." ("Reinventing Ritual," 29). The bluntness of the words zuo shengyi is what distinguishes the late Qing novel from its predecessors, although to be sure money is fundamental in all transactions involving prostitution, no matter what era. One thinks of the famous late Ming story about Du Shiniang and her betrayal by the literatus Li Jia. Earlier still, Yuan drama portrays street-smart and money-wise courtesans manipulating rich but foolish merchants (e.g., Guan Hanqing's "Jiu fengchen"[Saving one of the girls]). Zamperini also distinguishes the late Qing novel from its predecessors by referring to a new speed, "increasing acceleration," and "mobility" ("Lost Bodies," 83-84).

29 When the poet GaoYabai first meets her, however, he cannot see her attraction. The man introducing her then says, "You just wait. After you've seen her study [shufang], you'll realize how splendidly she's fixed it up!" (31.268). Gao is then impressed. Flowers of Shanghai also presents the notion that male customers who desire such women are rarer as well. The rarity of such men is captured in an exchange between Wen Junyu and Luo Zifu. When she tries to explain a poem to him, he says: "I don't understand poetry," and without stopping continues on his way upstairs (59.508). When literati men do appear, as Zamperini reports, they are often old fools unable to face up to the new realities of Shanghai ("Lost Bodies,"101). 
few men in the novel who themselves read and write classical verse, she is nevertheless portrayed as someone who is easily eclipsed by a more down-toearth prostitute, Zhao Guilin, also an opium addict. Zhao's madam at first tries to lure one of Wen's admirers ${ }^{30}$ by asserting that "drinking and playing cards" with Zhao is better than writing poems for Wen Junyu (59.511). He responds that such playing around is "too vulgar," but then reverses himself when Zhao's madam offers him an economical deal with Zhao and the prospect of sleeping with her that very night. ${ }^{31}$ The portrayal of this persuasion based on sex and the good deal is part of the broader picture that Flowers of Shanghai and other late Qing novels present of the business of prostitution which is the business of life in the foreign concessions of Shanghai. The poetcourtesan without customers is quickly rendered inactive and old-fashioned, that is, devoid of future. The gentility of classical taste can now hardly hold its own with the "true color of doing business," shengyi bense, as one merchant implies to another as they are about to attend an affair at the house of the literatus Qi Yunsou (47.402). ${ }^{32}$

\section{The Elite Prostitute and her Control of the Man}

\section{The successful prostitute}

We are now prepared to deal with specific situations - mises-en-scènes, in other words - which figure the elite prostitute's control of the man. By misesen-scènes I mean scenarios by which Han Bangqing captures essential moments of the prostitute-patron relationship, or through which he crystallizes certain psychic formations or mental turns. When and how, for example, does a patron decide that a certain prostitute is worth his monetary and emotional commitment? What types of deals are struck between prostitute and patron and how? What constitutes a successful prostitute, that is, one who has true benshi?

In general, we may say that the chief element of the man's relationship with the prostitute is the strength of her personality or, in other words, her aura. In the words of one patron, the man who "does" these prostitutes-the changsan or the shuyu in particular-does so for the sake of the "better reputation" he gets by associating with them. ${ }^{33}$ The aura of such a woman also

\footnotetext{
30 That is, the same who introduced her to Gao Yabai.

31 Zhao is an older prostitute who has begun to have trouble attracting customers, $60.512-13$; "old" in the context of late Qing brothels may start at twenty or so.

32 Shengyi bense is opposed to siwen qiangdiao, "cultured sophistication" (47.402).

33 The patron, Li Shifu, adds, however, that such a man is "truly an incompetent customer" (zhenzhen shi chantou keren, 15.127). Li instead saves money by going to cheaper prostitutes and supposedly getting the same thing or even something better than what the extravagant patrons get. He later contracts venereal disease.
} 
translates into her ability to hold and gain ground in general, both with a specific man and among the wider group of men and women in the brothel community. In such an arena, as characters in the novel often observe, her strength relates to how much she can control or channel (guan) the man by such things as prohibiting him from going to other prostitutes or compelling him to make and keep promises to her. The peculiar psychic formation that Flowers of Shanghai repeatedly foregrounds is that by which the man appears to seek, if not actually enjoy, being controlled by her in these ways. We must therefore go so far as to say that the man in fact defines himself-or seeks self definition, as I have said above - through a certain image he has of being "controlled" by her. If we accept this hypothesis of his self-definition, then we must assume that she constitutes a potentially sure foundation upon which he seeks to find footing. To get assurance of that footing, the man looks for signs of her control over him, in particular, control that she gains against his will. When she has furious outbursts of jealousy, for example, when all he begs for is for her not to be upset with him - it is at times like these that he is most delivered into her hands.

A key situation in which such control becomes crystallized is also one of the most sensitive situations in general in the brothel community, namely, the attempt on the part of the man to switch from one prostitute to another. When the patron Wang Liansheng tries to switch from Shen Xiaohong to Zhang Huizhen, Shen Xiaohong surprises Wang and Zhang in a public park where Shen physically attacks Zhang. Wang Liansheng never succeeds in severing himself from Shen Xiaohong, even after he later marries Zhang, who at one point wonders at Shen Xiaohong's "ability" (benshi) to be able to get Wang to continue being "good" to her (12.98). In another case, after the patron Luo Zifu switches from Jiang Yueqin to Huang Cuifeng, who forbids him from visiting Jiang anymore, Jiang says she has never seen a customer of Luo's high stature be so obedient (15.124). Later, Hong Shanqing's mistress compares a new and talented prostitute to Shen Xiaohong, saying that, like Shen Xiaohong, the new woman has "talent" (benshi) and can "make good for herself" (zhengqi). "She looks like someone who will go her whole life as a prostitute and never marry" (17.144). ${ }^{34}$

34 The new prostitute is Zhou Shuangyu. The phenomenon referred to in this last sentence is the option that many prostitutes take to marry out of prostitution. The prostitute Lin Sufen, for example, is resentful of the famous and older Tu Mingzhu, whom she labels a "fashionable" prostitute (shimao), a type of woman, Sufen says, who takes for granted the attention she gets and on top of everything "will not marry" (18.15556). As Henriot says, "marriage ... represents the possibility of exiting prostitution in an honorable way" (Belles de Shanghai, 70, my translation). The common counter-wisdom as represented in novels like Flowers of Shanghai is that these attempts risk failure due to the disapproval of the man's family or his lack of money and his tendency to use up her savings, which forces her to return to prostitution again. Another 
The successful prostitute as filtered through the above renditions is the woman who "knows how to do business," which in turn comes down to keeping a customer steady but also not marrying him. The image of the truly capable woman is someone who amasses enough wealth to buy herself out of prostitution, if she is owned (like Huang Cuifeng), and otherwise to live selfsufficiently for the rest of her life (few actually succeeded in these ways). ${ }^{35}$ The woman who fails, on the other hand, is the one like Zhao Erbao who counts naively on the man keeping his promise to marry her. The idea of the successful prostitute thus oddly corresponds to the tendency of the male customer to find a woman with whom he can undergo a thorough form of being controlled and whom he can never succeed in either marrying or abandoning.

\section{Becoming the son of the prostitute}

In fact the men in Flowers of Shanghai for the most part stay with one woman, several of them becoming significantly attached (not, of course, that this fact reflects some statistical reality). Everyone fills out what the author attempts to portray as a kind of complete scene of prostitution in Shanghai. The mediator-facilitator Hong Shanqing is the nearest the author comes to a character who represents the focal viewpoint of the novel. He is the one from whom all others are measured as they perform their antics while he roves through Shanghai in a constant series of rendez-vous and mediations. At the same time, he maintains an amiable relationship with his mistress Zhou Shuangzhu, who meanwhile earns her own income as she goes on calls (referred to as $j u$, which consists of attending banquets, parties, and other gatherings to which men invite them). Hong Shanqing is a middleman who settles conflicts, assists transactions, and in general makes a good part of his living (besides working at his ginseng store) off the wealthier men who trust him thoroughly. His goal is to keep women in business successfully, which means to keep men on their course of spending and paying up and to try to prevent or settle situations in which men or women become too emotionally involved. In other words, he keeps the love fantasy going, but does not want it to stretch beyond the proportions of doable business.

\footnotetext{
common wisdom points to prostitutes notorious for wasting the man's money or returning to prostitution because of an intolerance for the restrictions of marriage. The woman's perspective in this situation is difficult to know because of the paucity of sources written by these women (but see Zamperini on Sai Jinhua, "Lost Bodies"), but it appears that becoming a concubine was more likely than becoming a main wife, and that concubinage was a desirable option for both the men and women involved. As Yeh points out, it appears that it was common for men to take concubines from among the ranks of courtesans ("The Life-style of Four Wenren," 456).

35 Henriot writes that women did not remain as prostitutes for very many years (Belles de Shanghai, 152, 257-58). Women who could free themselves independently were rare. Age and ill-health were the main reasons for the high rates of replacement (38).
} 
Ideally, the new Shanghai prostitute can manage her own affairs without his intervention. Wu Xuexiang is such an example, a woman who succeeds in gaining her client's loyalty and even marrying him as the father of their child. She and Ge Zhongying are the one couple, in fact, whose story culminates in a happy pregnancy (47.403). If their story can be assigned a symbolic purpose, moreover, it is to show how a prostitute can supposedly achieve lasting harmony with her customer. In an early scene she is angry at him for staying too long at another prostitutes's place across from Wu's. Wu insists that $\mathrm{Ge}$ obey her and go only where she allows him to go, for "You are my son," she suddenly proclaims (6.42). She is so proud, moreover, because her "son" sports in brothels, thus "giving her great face," she adds sarcastically. Then she concludes that if she had her own son, she would "beat him to death" if he went to brothels. "She is crazy today," Ge says to the maid standing by, after which he and Wu "playfully tussle for a bit" (guihun yizhen, 43). But when it comes to him then announcing that he wants to go out by himself, to his surprise she insists on going with him and he cannot convince her otherwise. Thus the playfulness of their banter transforms into something with the real effect of Wu Xuexiang obtaining her way regarding not only Ge's visitation of her quarters, but also his independence abroad. She controls him more than his wife does, he declares. ${ }^{36}$

As fanciful as this story may be, Wu's behavior in fact points to an important feature of the new Shanghai courtesan. Her mobility and independence signal a real change in male and female behavior in the foreign concessions. ${ }^{37}$ Self-promotion by way of increasing business went hand-in-hand with the new freedom that women had to move about and be seen in public without being subject to legal or customary restraint. The best example of this evolution is what Ge Zhongying and $\mathrm{Wu}$ Xuexiang do shortly after the above exchange. They go out together to a "foreign store," where they make purchases in a manner that is hardly different from other modern couples who go shopping downtown. Although they are patron and prostitute, she is pregnant with his child and they will soon marry, thus looking like incipient middle-class consumers of Shanghai.

\section{The man who is afraid of his wife}

Another case of a patron bowing to the successful prostitute is that of Yao Jichun, a man who is afraid of his wife. Wives storming into brothels in search

\footnotetext{
36 Already married, he will perhaps take $\mathrm{Wu}$ as a concubine and set her up in a separate household, but these details are not provided.

37 As Yeh writes, "[ $[$ ]he Shanghai courtesan took advantage of the fact that the public space in the Settlements was open to them" ("Reinventing Ritual," 11).
} 
of their husbands is something of a stock episode in courtesan stories. When Yao's wife storms into the brothel of Wei Xiaxian in search of her husband, Wei tells her that any man who enters this door is no longer anyone's husband. "If you have the ability (benshi), then you may take control of your husband" (23.196-97). Otherwise, "we operate this brothel to do business; once someone enters, he is our customer." Later Yao Jishun sees a lesser prostitute, Ma Guisheng, who is a yao'ni as opposed to the formidable Wei, a changsan. He cowers when his wife again visits the brothel, but this time Ma and his wife form an alliance. Ma says to the wife that she by all means should control her husband, otherwise he would sleep with every prostitute in the foreign concessions (57.487-88). The wife decides that she likes Ma as long as Yao only stays with her.

"Those who enter this door are our customers, they are no longer anyone's husband," presents us with the idea that when the man enters a brothel, he undergoes a transformation similar to that of crossing the bridge between China and the Shanghai concessions. A revaluation suddenly takes place whereby one is turned into one's "opposite": formerly a husband, subject to but privileged by the traditional patriarchal order, now a customer, free to spend money on whatever is new and entertaining, but subject to whatever the woman declares is a cost. The cases of Ge Zhongying and Yao Jichun both exemplify the man who is "fearful of his wife" (junei, papo), as made famous in scores of novels, stories, and plays from the Ming and Qing. ${ }^{38}$ The elite prostitute of Shanghai is made just for him and knows precisely how to transform him into someone who is as fearful of her as of his wife, if not more so.

\section{Stolen from the patriarchal order}

As two young people who fall in love, Zhu Shuren and Zhou Shuangyu exemplify the kind of relationship that Hong Shanqing and others try but fail to prevent. Zhou Shuangyu, a newly bought prostitute (taoren), is the woman whom Hong's mistress compares to the formidable Shen Xiaohong for likewise being a woman of nerve and talent. The naif Zhu Shuren falls in love with Zhou Shuangyu, his first prostitute and probably the first eligible young woman he has ever met. He promises to marry her as his main wife, but his elder brother secretly arranges a marriage for him back home. Shuren and Shuangyu have meanwhile sworn a suicide pact (to take effect on the lovers' festival of the seventh day of the seventh month, when the Oxherd and Weaving Maiden have their once-a-year meeting). When she discovers his betrothal,

38 See Yenna Wu, The Chinese Virago: A Literary Theme (Cambridge: Harvard University Press, 1995), and Keith McMahon, Misers, Shrews, and Polygamists: Sexuality and Male/Female Relations in Eighteenth-century Chinese Fiction (Durham: Duke University Press, 1995). 
she challenges him by presenting him with a cup filled with opium solution, a common method of suicide (ch. 63). He resists, but she is furious: she will be main wife or she will die. The outcome is a deal arranged by Hong Shanqing: a sum of money to redeem Shuangyu from prostitution and to buy a settlement with the woman's family to whom Shuren was betrothed (in the end Zhu marries neither woman). Shuangyu yells at Shuren: "For $\$ 10,000$ you bought your life. You got off cheap!" (64.547). Zhu Shuren meanwhile cowers behind Hong Shanqing. Zhu resembles Tao Yufu whose lover Lin Shufang dies of tuberculosis because of Tao's family's opposition to their marriage. Both young men pale before women to whom they virtually grant power of life and death. ${ }^{39}$

Both women are examples of prostitutes who in effect steal men away from the patriarchal order, which they overturn by transforming marriage into something else: their self-chosen contract between prostitute and customer in the foreign concessions of Shanghai. In the process of accomplishing this theft, they stipulate the conditions under which they must be treated, regardless of the man's other relationships with family and male friends. Lin Shufang blames Tao for not caring for her well enough and for not always thinking of her. $\mathrm{He}$ concludes that he is indeed "bad" and has "harmed" her (18.148), and thereafter cares for her day and night until she dies. Again, the prostitute makes the man more fearful of her than of the woman-wife she comes to replace. The business of prostitution enables her to develop acute talents of conducting that business to her own specifications. Her best customer, moreover, is someone she calls into being without him knowing it. He invites himself there as a way of becoming a full-fledged person perfectly needed by the woman who calls him into being.

\section{The powerful prostitutes}

Two other men, Luo Zifu and Wang Liansheng, have yet more powerful mistresses who manage to avoid marriage, suicide pact, or love-death, but keep these men bonded to them nevertheless. Both mistresses have a second, secret lover, although only one of the women, Huang Cuifeng, succeeds in keeping her lover secret. The difference between the two women lies in the status of the second lover. In the case of the successful Huang Cuifeng, both of her patron/lovers are of the same social status and both provide her with financial benefits. Shen's secret lover is an actor, someone from whom the

\footnotetext{
39 After Lin Shufang dies, the young Tao is as if no longer interested in women (when others gather around a set of erotic illustrations, Tao displays no interest, ch. 47). He refuses to marry Li Wanfang, the younger women Shufang told him to marry after she dies.
} 
prostitute earns no money because she personally chooses him outside the contractual arrangements of the brothel.

Luo Zifu provides an excellent example of the mental turn that occurs in a man when he decides that a certain woman is the one for him. Once he becomes her favored customer, it is as if he becomes her subject and as such subjects himself to what a prostitute does to a man: she "fleeces" him (qiao). Luo is also an example of how a man chooses a prostitute based on what he hears about her from another man. A friend tells Luo of Huang Cuifeng's great temper and how she can hold her own with her madam, who herself is renowned as one of the toughest in the foreign concessions. The madam had once surrendered to Cuifeng when as a virgin prostitute Cuifeng tried to commit suicide by swallowing raw opium (6.47). As Luo's friend says of Huang Cuifeng, "If a customer makes her get her dander up, then all her tantrums and histrionics are a splendid sight to see" (6.46-47). Luo Zifu is struck by his friend's account and at that point decides to leave Jiang Yueqin, the prostitute he had been with for several years, and switch to Huang Cuifeng.

Once Luo becomes Huang's customer, she presents him with her stipulations: besides having him leave a chest full of important papers at her brothel as a kind of lien, she states that as for money - not as important as the chestshe will take it from him when it pleases her. But if it pleases her for him to "give her a brick," then a brick will be better than money (8.61-62). "You are truly a rare one," he says in awe. When they discuss her business, she declares that she will only "do" him, and that he will only do her. "So you can fleece just $m e$ then!," he responds. "If I only do you, then if I don't fleece you, who else will I fleece?," she replies (9.74). But Cuifeng does see another customer (Qian Zigang), from whom she asks help in buying herself out from her madam, Huang Erjie. Luo Zifu, who helps her as well, does not know about the other affair. ${ }^{40}$

If the madam Huang Erjie and the prostitute Huang Cuifeng exemplify women who are successful in cheating their customers, Shen Xiaohong is an example of a powerful prostitute who nevertheless miscalculates and loses her business. In the brothel community of Shanghai, a prostitute involved with an actor is a well-known type of affair which creates extreme sensationalism and notoriety. A fine line exists between the notoriety which works against the prostitute and that which makes her even more famous and desirable. In Shen's case, her hitherto steady patron, Wang Liansheng, himself walks in on her and the actor. Instead of a sensational bit of news about some famous

\footnotetext{
40 Nor, after Cuifeng's redemption, does he know about her plot to help Huang Erjie blackmail him by stealing his chest of important papers (chs. 58-59; Luo then pays Huang Erjie a large sum to get his chest back).
} 
prostitute, the prostitute and her actor-lover become in this case all too concrete for the man who is actually cuckolded. Realizing that she has crossed a fatal boundary, Shen outright denies that she had the affair. Her relationship with Wang is the most complex one in Flowers of Shanghai, but for our purposes provides an extended portrayal of the male customer's inability to tear himself away from a woman who aggressively hangs on to him, even if he feels betrayed by her.

In the period before Wang discovers her affair, his attachment to her comes down to a simple effect: he cannot stand her to be angry or displeased with him and will do anything to keep her from being angry. In fear of that anger, he does not tell her that he has taken a new prostitute. When Shen finds out, and when he finally faces her about it, she reacts with rage, even faking suicide, at which point he does precisely what is called for: he demonstrates in sincere, well acted-out fashion that (1) he will never see the new woman, Zhang Huizhen, again, and (2) he will pay off Shen Xiaohong's debts. That is, he reacts in a convincingly desperate fashion, which finally satisfies her (he does not carry through on breaking with Zhang Huizhen, but does pay Shen's debts; chs. 10-11, especially 85-86). Satisfying her in this way is a sign of his deep-set urge to hold on to her even as he switches to another prostitute. In fact, he is acting as patrons often do who go from one prostitute to another. But why can't he carry on smoothly? Shen plays on this instability of his when she says: "Your getting so angry with me just shows how much you want to stay with me" (34.292). He wears the scratches she makes on his arms and legs, which others see and know about (Shen's rival, Zhang Huizhen, tells Hong Shanqing about the scratches, adding, "his fear of Shen Xiaohong is boundless," 33.279). Wang has tears in his eyes when A Zhu, Shen's former servant, later tells him how poorly Shen is doing after he has left her. The others in the room at the time fall silent, while Hong Shanqing changes the subject (57.489).

The precise change that occurs when Shen Xiaohong is discovered having an affair with an actor should tell us more about the subtle nature of the woman's control over the man. Before this, Wang wanted to marry her, as he complains to Zhang Huizhen, but Shen kept delaying, even after he paid off her debts (24.202-203). When he openly accuses her of pin xizi, "having an affair with an actor," however, she begs him to listen to her and retract the accusation (ch. 34). In such a situation, a prostitute's desperation stems from the fact that this is an accusation that can be ruinous to her. When a prostitute has a personal lover or enke, especially an actor (who is of a lower class than her normal customers), she is in effect acting as a private person, no longer on contract to the brothel, which earns no money from such affairs. Moreover, gossip spreads, even appearing in the newspapers, which at first may enhance her 
reputation. But it may also happen that she loses customers or that customers who owe her money feel free to "float" (piao) their bills, that is, not pay up. It is as if the aura of her attraction has ended and as if that aura was only a matter of the performance of brothel business after all.

By way of further representing the reality of the performance of that business, the facilitator Hong Shanqing intervenes at this point in order to urge Wang to pay what is due to Shen Xiaohong, for that is Wang's responsibility. Regardless of Shen's behavior, Wang has run up a considerable bill as her exclusive customer (34.288-89). Hong Shanqing had warned Wang about Shen to begin with, but nevertheless stands for the view that once bills are due, then the prostitute's business (which includes Shen's pressure to support her immediate family) is more important than emotional entanglements. As a business woman, Shen took the risk of becoming too reliant on one customer, whom she now desperately tries to get back. She asserts that she could not have had the affair with the actor because only rich and "fashionable" prostitutes whose "business is good" can afford to do such things (34.292). Shen does manage to lure Wang back into bed. They lie down, as the narrator says, and then, "we don't know how many tender feelings and loving words may have passed between them" (34.294). But Wang immediately marries Zhang Huizhen anyway, without telling Shen. When news later spreads of her seeing the actor yet again (ch. 41), the little hope Wang had of continuing to see her completely evaporates. In a final twist, he does recommence "doing" her when he discovers his new wife Zhang Huizhen having an affair with his nephew, but Wang soon departs dejected and alone for an official post in another province.

Shen is a prostitute who is bound to "get her air," zhengqi. What does she do wrong? Prostitutes have affairs with actors all the time, Huang Cuifeng says, implying that Shen Xiaohong did not do it right (56.481). ${ }^{41}$ Huang Cuifeng blames Shen for making the wrong move when she did not marry Wang when he wanted to. If she had married him, Shen would now have a choice either to follow him to his post in Jiangxi Province or to "go out again and do business" with her reputation still intact (56.480).

Regardless of Shen's miscalculation, there is a more important angle from which to regard her affair with Wang, namely, to see how doing business well comes up against (or overlaps with) the question of whose pleasure will have more weight, the client's or the prostitute's? The ostensible answer should be the client's. In the case of the exemplary prostitute like Shen or Huang, how-

\footnotetext{
${ }^{41}$ As one who also cheats her customer Luo Zifu by concurrently seeing Qian Zigang (who knows about her and Luo), Huang Cuifeng repeatedly implies that she is cleverer and more cautious than Shen. She says, for example, that Shen should not have attacked Wang openly but instead should have applied pressure to him in a less obvious way (481).
} 
ever, she stakes claims that at times supersede those of the client. We cannot make the mistake of thinking that the prostitute thereby "wins" or that she obtains some kind of enduring spoil, but she does succeed in derailing the man and making him unable to harvest his usual claim to pleasure. As Catherine Yeh puts it, the Shanghai courtesan "reset[s] the balance in her relationship with her client." 42

\section{Hong Shanqing and the Self-dissolving Fantasy}

\section{Brothel facilitator}

The remarkable aspect of Huang Cuifeng's comments about Shen Xiaohong, of Shen's own defense of herself, or of Hong Shanqing's urging Wang to pay Shen's debts is the absence of reference to the theme of the lascivious woman, including the absence of defense against that accusation. Luo Zifu comes the closest when he says that, in having an affair with an actor, Shen is "doing it for her own pleasure," a statement that Huang Cuifeng immediately dismisses (56.480). The theme of the lascivious woman is prominent on the first page of Flowers of Shanghai in the form of the warning about women being "more vicious than a yaksha." Thereafter the theme appears in compressed form in Luo's comment and in Wang's anger and bad feelings about being cuckolded. But what the novel mainly foregrounds in the blame laid upon Shen is her miscalculation, her "bad decisions" (56.480), not the idea that she is unbridled and lascivious and therefore destructive of men. If in taking a lover, she "does it for her own pleasure," the author is far from portraying her in the way of stories like Water Margin, to take the extreme example, in which the betrayed man brutally murders the "lascivious woman," yinfu.

The role of Hong Shanqing in the novel is key to this unreadiness to plunder the theme of lascivious yaksha. His impetus is to maintain a low and manageable level of fantasy between customer and prostitute. If the fantasy grows too unwieldy, he attempts to divert or rechannel it, which is in essence to expose it as something artificial and contingent. The exposure of others' overblown fantasies, to be sure, is an effect of Hong Shanqing's words and actions, not something that he or the narrator articulates explicitly. His role, moreover, is not in the tradition of the exemplary hero, brilliant and valiant. Instead, he is a new type of man, one who supersedes the now maladjusted scholar-literatus and who is newly agile in adapting to the changing environment of a city like Shanghai. His role can in fact be given a particular label: he is the facilitator of brothel affairs. Even more apt, he is a kind of overseer of the love fantasy. His position is that of exposing other subjects to their entrap-

\footnotetext{
42 Yeh, "Reinventing Ritual," 52.
} 
ment in the fantasy of love, which at times overlaps with their fantasy of the glittering world of Shanghai.

The most crystallizing image of Hong Shanqing appears as he wakes one morning in bed with his mistress-prostitute Zhou Shuangzhu: "Shanqing was just at that moment on a hunting excursion in the plains of dreamland [Nankejun] with the Imperial Princess" (17.145). He is awakened from this dream by someone looking for him to attend to an emergency. The dream is as near as the author comes to a subjective, that is, self-conscious laying open of the male fantasy which the book otherwise conveys in a more objectivized fashion. Here, however, it is as if the author curls himself up inside the sleeping Hong Shanqing, who does his fantasizing in dreamland then wakens to attend to the fools in Shanghai. In this case, the fool is the naif Zhao Puzhai from Shanqing's home village, who has gotten himself beaten up in one of the low-class brothels in the French Concession (17.146). Hong's dreamland is the blatantly false and therefore the safest one, no illusions about it, of "Nankejun." This is the name used in the classical trope about a man who goes to sleep and dreams of another life in which he marries a princess, serves in high office, receives wealth and glory, then experiences utter failure, after which he wakens and realizes the vanity of life. ${ }^{43}$ In the classical trope the result of the dream is enlightenment. In Hong Shanqing, the theme of the vanity of life is old hat and has turned into something else, namely, self-dissolving fantasy. In other words, Hong indulges his fantasy anyway, knowing it is vain, and then he is ready to dissolve it. It is as if he knows there is no imperial princess and that even if there was one she would not go on an excursion with him. His dream put aside, he goes back on call after the hiatus of sleep and the previous evening of chatting and smoking opium with Zhou Shuangzhu.

It is Hong's "job," the one he returns to after he is awakened, that colors this dream as a self-dissolving fantasy. As I have said, he is a facilitator and go-between for transactions between customers and prostitutes. These transactions involve the negotiation of both business and emotional relations. Besides facilitating and negotiating, he also strives to keep the business fair and respectable and to prevent relationships from becoming explosive or otherwise unmanageable. Thus, when Wang Liansheng requests that Hong help purchase furniture for Zhang Huizhen's new apartment, Hong opposes the idea because he knows of Shen Xiaohong's furious temper (4.27-28). Wang has "kept" Shen exclusively for several years. Now, however, without telling Shen, he is engaging to switch to Zhang, ${ }^{44}$ and to move Zhang to better ac-

\footnotetext{
43 The original story is by Li Gongzuo (circa late eighth to early ninth centuries), "The Governor of Nanke."

${ }^{44}$ Zhang is a lower-class "yaoni" prostitute, unlike Shen or Huang who are changsan.
} 
commodations (such a switch is called tiao cao, "jumping troughs," 4.29). Hong's other concern is that Wang has not paid Shen's debts, but at the same time will have to spend a considerable amount to establish and maintain Zhang Huizhen. Later, after Shen viciously attacks Zhang in the park, Hong still stands for the principle that Wang should face Shen and pay her debts (ch. $34)$.

In fact, his interest in maintaining the business of prostitution is at times blithely oblivious of the dangers of emotionally involved patrons and prostitutes. He steers together the young Zhu Shuren and the virgin prostitute Zhou Shuangyu, both too new to the business to go unwatched..$^{45}$ When Zhu's elder brother worries that Shuren will lose control when it is too late to restrain him, Hong Shanqing "knows what he [the elder brother] is talking about" (32.273). Hong agrees to help look in on the two, but it is already too late. His original interest was to help the young Zhou Shuangyu get a foothold and begin to do a "full-fledged business" (zuo da shengyi) by "lighting the big candle" (dian da lazhu), the euphemism for the occasion of the virgin taking her first sexual customer (32.277). Much later, after Shuangyu has refused to take other customers overnight (57.490), and then after she has attempted suicide upon learning of Zhu Shuren's proposed marriage to someone else, Hong Shanqing succeeds in arranging a settlement (ch. 64). But just before learning that their affair is in danger, Hong tells his mistress Zhou Shuangzhu that it is a pity Wang Liansheng is leaving Shanghai, for otherwise he could take up with Zhou Shuangyu (57.490). In other words, with the business of Wang Liansheng and his affairs with both Shen and Zhang gone terribly bad, and with Zhu Shuren now getting married as arranged by his elder brother, Hong Shanqing is ready to restart the clock by at this point putting Wang together with the woman (Zhou Shuangyu) whom Zhu Shuren has just left.

This attempt to create a new couple, regardless of the ongoing predicaments of the man and woman involved, is another crystallizing image of Hong Shanqing in his role as overseer of the fantasy of love. One could accuse him of being too oblivious of the consequences of people's entanglements or even of being too anxious to return to business as normal, from which he and his mistress make a living. But it is impossible to ignore the alternative that restarting the clock performs the function of blanking out and dissolving overblown fantasies, whether in obsessive men or hysterical women. Hong's mistress (Zhou Shuangzhu) is his sometime comrade in this role of analyst and observer. In idle moments before bed they compare Shen Xiaohong and Zhou Shuangyu (17.144). The analyst's words come through her mouth and that of others throughout the novel in the form of truths about the affairs of prostitu-

45 Zhou Shuangyu is not the same as Hong's mistress Zhou Shuangzhu. 
tion. Hong's mistress advises Shuangyu: "As a prostitute, a woman can only do so much, even if she has talent and can make good for herself. Keep this in mind, now, and make the best of what you've got" (17.142). The mistress later tells Shuangyu that Zhu Shuren did her wrong by not telling her of his betrothal. But "you're too young and naive. How could you believe the promises of a customer!? Even if Shuren had not gotten engaged, he'd never be able to take you as main wife!" (63.543). Another woman ${ }^{46}$ asks Hong Shanqing in mock wonderment (so as deliberately to pester Zhou Shuangyu who is within earshot): why do so many prostitutes want to become main wives? She lists the examples: Lin Shufang, Zhao Erbao, and now Zhou Shuangyu (62.537).

\section{The new Shanghai citizen}

In the Shanghai of late Qing novels like Flowers of Shanghai, as I have been emphasizing, the role of the traditional master has weakened. The main restraint upon the brothel patron takes the form of relatives or friends (especially those from "back home") who warn him about his excesses and about the male and female swindlers of Shanghai-thus Hong Shanqing who repeatedly warns his rural nephew Zhao Puzhai. If he is to survive and not go broke or be "fleeced," he must adopt a new persona, even emulating the Shanghai prostitute who has to survive repeated displacements and thus be agile in adapting to new circumstances.

Hong Shanqing is an example of the new type of man in Flowers of Shanghai. As the novel demonstrates from the very start, he constantly moves from one gathering to another, following a business lead here, closing a deal there, and throughout performing his nebulous job as brothel facilitator. His quintessential moment is to be walking the Shanghai streets from one engagement to another and then being sidetracked as he runs into someone looking for him. His counterparts in other novels are men like Han Qiuhe in Zou Tao's Shadows of Shanghai Dust (1897), or Zhang Qiugu in Zhang Chunfan's Ninetailed Turtle (1910). Han Qiuhe's wondering takes him all over the world, including California's gold mines, although in his case he still retains Baoyulike attachments to a prostitute in Shanghai. Zhang Qiugu knows the ways of Shanghai brothels and, like Hong Shanqing, advises both prostitutes and patrons, although he is more self-certain than Hong Shanqing in his superherolike way of never getting duped in Shanghai. ${ }^{47}$

6 Zhou Shuangbao, a prostitute in Shuangyu's and Shuangzhu's brothel whom neither of them likes.

47 On Zhang Qiugu, see also Wang, Fin-de-siècle Spendor, 81-88, and Zamperini, "Lost Bodies," 103108 . 
At the center of the world of this new persona is an emerging consumerism, which the promotion of brothel business heartily advances. One of the finest illustrations of consumerism demonstrates the new imperative of capitalistic Shanghai, which is to spend and enjoy. When the soon-to-be-married Ge Zhongying and Wu Xuexiang shop in the "foreign store," they see all sorts of objects they have never seen before and for which they have no names (6.43-44). They look until "their eyes are blurred and their minds go numb" (muxuan shenjing). Movable wind-up toys - people, animals, boats, and carriages - are among the things they view.

To buy what one did not know one needed to buy and did not even know the name or use for crystallizes the imperative of spend and enjoy. One becomes a new person by this act of shopping: a citizen of the new city of Shanghai. Hong Shanqing's niece Zhao Erbao is similarly fascinated with the novelties of Shanghai, but she fails to learn the ropes and adheres too strongly to the romance of marriage and loyalty. When she wants to leave the brothel and become a proper married woman, she cannot do so because of the insincerity of her lover Shi Tianran's promise. He is merely fulfilling the nature of the male customer. She must then fall back into the cycle of merchandising herself, her resistance to which causes the gangster Lai and his thugs ferociously to wreck her apartments (ch. 64). Ge Zhongying and Wu Xuexiang, on the other hand, manage their modernization more efficiently, making their purchases and leaving the store, later to marry and have a child.

When Hong Shanqing refuses to help Zhao Erbao out of her predicament, she says, "he looks down on us." How can he do that, she continues, "when his business is no different from what we do as prostitutes in the brothel!" (64.548). In other words, Hong Shanqing's job as facilitator is also like prostituting himself and living off the fancies of male customers. He, of course, can maintain a comparatively greater distance from the customers with whom the prostitutes actually have to sleep. Instead, he finds himself a safe haven in the brothels, apart from imperial China and no longer jostling with the literati crowd.

As new figures in Chinese fiction, he and his courtesan Zhou Shuangzhu, along with couples like $\mathrm{Ge}$ and $\mathrm{Wu}$, have a grasp on what we might call the currently emerging love fantasy, whose new dictum is that there are no love matches made in heaven. No matches in heaven also translates into no matches dictated by family alliances. In other words, in the obvious sense the marriage of $\mathrm{Ge}$ and $\mathrm{Wu}$ is something that they accomplish on their own, without the external hand of the elders. But the sense of external hand should also be thought of as the hand of fate or heavenly predestination, such as that which is embodied in Baoyu's jade and Baochai's golden locket or other such love tokens or auspicious symbols. Grand romantic gestures such as severing a 
part of one's flesh for the sake of one's beloved (an act which Han Qiuhe still performs in the later novel Shadows of Shanghai Dust) are likewise old-fashioned.

Hong Shanqing exemplifies yet one further, crucial sense of those times, the lack of paranoia at the loss of footing experienced by the former male hero, however that hero is labeled (e.g., polygamist, literatus, wastrel). In other words, he never expresses a nostalgic desire to withdraw from Shanghai and go back to the country. He also resists fascination with Shanghai's attractions. At the same time, although he is impervious to becoming overly fascinated and hence duped, he is also free of the self-certainty of never being duped. Self-certainty carries within it an ultimate sense of resentment that Hong Shanqing likewise fails to express. We should even go further and say that self-certainty in such a situation is like an empty place holder for the absent or weakened father of traditional China, while resentment is resentment at the fact that this father has been undermined and weakened in this new environment to which the subject is forced to adapt. ${ }^{48}$ In other words, the self-certain subject (like Zhang Qiugu in Nine-tailed Turtle) in the brothel world of the Shanghai foreign concessions represents a resurrection of that father who is in fact already lost. Hong Shanqing, on the other hand, is closer to the prostitute who takes her chances and sometimes gets a good deal, but sometimes miscalculates. When unexpected things happen (such as Wang Liansheng's attempt to leave Shen Xiaohong), Hong Shanqing can only wonder to himself how unstable and unpredictable things have become in the world (35.296). He can attempt to repair the situation, but otherwise he can only shake his head and move on to his next rendezvous.

My point in concluding is that in the foreign concessions of Shanghai where the role of the traditional male hero is weakened, Hong Shanqing is in effect a replacement for that hero, not a latter day reincarnation. He may not constitute an admirable figure from the perspective of May Fourth ideology. He has no overtly political vision and he still engages in quintessential acts of supposed decadence such as smoking opium and consorting with prostitutes. But he has already made the definitive step away from the positions of either sentimental nostalgia or reactionary reconstruction vis-à-vis the traditional past. His position becomes the clearest when viewed in terms of his relations with the prostitute-yaksha. On the one hand, he neither venerates women by attempting to find among them someone who still represents old-fashioned ideals. Nor, on the other hand, is he on a vengeful mission to spread the word about the deceitful prostitute, as if trying to vindicate victimized men. He has

48 See Zamperini's comments on the insecurity and disorientation of men, especially the old-fashioned wenren (literatus), in Shanghai ("Lost Bodies," 82-98, 111-116). 
a grasp on the currently emerging love fantasy, in other words, and does so by identifying with the icon of the new lifestyle of the modernizing Chinese city, the Shanghai prostitute.

\section{Glossary}

\begin{tabular}{|c|c|c|c|}
\hline A Zhu & 阿珠 & Ernü yingxiong zhaun & 兒女英雄傳 \\
\hline Banqiao zaji & 板橋雜記 & Gao Yabai & 高亞白 \\
\hline Bian Sai & 市賽 & Ge Zhongying & 葛仲英 \\
\hline Bao Tianxiao & 包天笑 & guan & 管 \\
\hline benshi & 本事 & Guan Hanqing & 關漢卿 \\
\hline Cai Erkang & 蔡爾康 & guihun yizhen & 鬼混一陣 \\
\hline cainü & 才女 & guolairen & 過來人 \\
\hline changsan & 長三 & Haishang chentianying & 海上鹿天影 \\
\hline Chen Zilong & 陳子龍 & Haishang fanhuameng & 海上繁華夢 \\
\hline Chen Xiaoyun & 陳小雲 & Haishanghua liezhuan & 海上花烈傳 \\
\hline Chen Yinke & 陳寅恪 & \multicolumn{2}{|c|}{$\begin{array}{l}\text { Haishang zi tongshang yilai } \\
\text { 海上自通商以來 }\end{array}$} \\
\hline Dagouqiao & 打狗橋 & & \\
\hline daotai & 道台 & Han Bangqing & 韓邦慶 \\
\hline & & Han Qiuhe & 韓秋鶴 \\
\hline Dangkouzhi & 蕩寇志 & Hu Shi & 胡適 \\
\hline dian da lazhu & 點大蠟燭 & hua & 華 \\
\hline Du Shiniang & 杜十娘 & huayanjian & 花煙間 \\
\hline enke & 恩客 & Hong Shanqing & 洪善卿 \\
\hline
\end{tabular}




\begin{tabular}{|c|c|c|c|}
\hline Huayuehen & 花月痕 & Liu Rushi & 柳如是 \\
\hline Huang Cuifeng & 黃翠鳳 & Liu Xizai & 劉熙載 \\
\hline Huang Erjie & 黃二姐 & louxi & 陃習 \\
\hline Huang Zunxian & 黃遵憲 & Lü mudan & 綠牡丹 \\
\hline Jiang Yueqin & 蔣月琴 & Lu Xun & 魯迅 \\
\hline jindai & 近代 & Luo Zifu & 羅子富 \\
\hline Jiu feng chen & 救風鹿 & Ma Guisheng & 馬桂生 \\
\hline Jiuweigui & 九尾龜 & muxuan shenjing & 目眩神惊 \\
\hline ju & 局 & Nanke jun & 南柯郡 \\
\hline junei & 懼內 & Niehailhua & 菣海花 \\
\hline Kuhaihang yuefu & 苦海航樂府 & pa po & 怕婆 \\
\hline Li Boyuan & 李伯元 & Pan San & 潘三 \\
\hline Li Ciming & 李慈銘 & pian & 騙 \\
\hline Li Gongzuo & 李公佐 & piao & 漂 \\
\hline Li Jia & 李甲 & Pinhua baojian & 品花寶鑑 \\
\hline Li Shifu & 李實夫 & pin xizi & 姘戲子 \\
\hline Li Shufang & 李淑芳 & Qi Yunsou & 齊韻叟 \\
\hline Li Wanfang & 李浣芳 & Qian Qianyi & 錢謙益. \\
\hline Li Zhuanhong & 黎䇡鴻 & Qian Zheng & 錢徵 \\
\hline Lin Sufen & 林素芬 & Qian Zigang & 錢子剛 \\
\hline
\end{tabular}




\begin{tabular}{|c|c|c|c|}
\hline qiao & 敲 & Wang Liansheng & 王蓮生 \\
\hline qingguanren & 清倌人 & Wang Tao & 王蹈 \\
\hline Qingloumeng & 青樓夢 & Wen Junyu & 文君玉 \\
\hline Sai Jinhua & 賽金花 & wenren & 文人 \\
\hline Sanxia wuyi & 三俠五義 & Wu Weiye & 吳偉業 \\
\hline Shenbao & 申報 & Wu Xuexiang & 吳雪香 \\
\hline Shen Xiaohong & 沈小红 & Wu Jianren & 吳趼人 \\
\hline shengyi bense & 生意本色 & xianshen shuofa & 現身說法 \\
\hline shimao & 時髦 & xiucai & 秀才 \\
\hline Shi San Gongzi & 石三公子 & Xu E & 徐鄂 \\
\hline shufang & 書房 & yang & 洋 \\
\hline shuyu & 書寓 & yao'er & 么二 \\
\hline siwen qiangdiao & 斯文腔調 & Yao Jichun & 姚季專 \\
\hline Tao Yufu & 陶玉甫 & Yao Xie & 姚夑 \\
\hline Tao Yunfu & 陶雲甫 & yeyou zidi & 冶游子弟 \\
\hline taoren & 討人 & yinfu & 淫婦 \\
\hline tiao cao & 跳槽 & Yu Huai & 余懷 \\
\hline Tu Mingzhu & 屠明珠 & Zeng Pu & 曾樸 \\
\hline Wei Xiaxian & 衛霞仙 & Zhang Ailing & 張愛玲 \\
\hline Wang A'er & 王阿二 & Zhang Chunfan & 張春帆 \\
\hline
\end{tabular}




\begin{tabular}{|c|c|c|c|}
\hline Zhang Huizhen & 張惠貞 & Zhou Shuangzhu & 周雙珠 \\
\hline Zhang Qiugu & 章秋谷 & Zhu Ailin & 朱愛林 \\
\hline Zhao Erbao & 趙二寶 & Zhu Airen & 朱䍖人 \\
\hline Zhao Guilin & 趙桂林 & Zhu Sanjie & 諸三姐 \\
\hline Zhao Puzhai & 趙樸齋 & Zhu Shiquan & 諸十全 \\
\hline \multirow{2}{*}{\multicolumn{2}{|c|}{$\begin{array}{l}\text { zhenzhen shi chantou keren } \\
\text { 真真是鏟頭客人 }\end{array}$}} & zhuzhici & 竹枝詞 \\
\hline & & Zhu Shuren & 朱淑人 \\
\hline \multirow[t]{2}{*}{ zhengqi } & 爭氣 & & \\
\hline & & Zou Tao & 鄒㢷 \\
\hline \multirow[t]{2}{*}{ Zhou Shuangbao } & 周雙寶 & & \\
\hline & & zuo da shengyi & 作大生意 \\
\hline \multirow[t]{2}{*}{ Zhou Shuangyu } & 周雙玉 & & \\
\hline & & zuo shengyi & 作生意 \\
\hline
\end{tabular}

\section{References}

Carlitz, Katherine. 1997. "Desire and Writing in the Late Ming Play Parrot Island." In Widmer and Chang, ed., 101-130.

Chang, Kang-i Sun. 1997. “Ming and Qing Anthologies of Women's Poetry and Their Selection Strategies.” In Widmer and Chang, ed., 147-170.

Chen Bohai, Yuan Jin, et al. 1993. Shanghai jindai wenxueshi. Shanghai: Shanghai renmin chubanshe.

Chen Yinke. 1980. Liu Rushi biezhuan. 3 vols. Shanghai: Shanghai guji chubanshe.

Gu Bingquan. 1996. Shanghai yangchang zhuzhici. Shanghai: Shanghai shudian chubanshe.

Han Bangqing. 1997. Haishanghua liezhuan. Haikou: Hainan chubanshe.

Henriot, Christian. 1997. Belles de Shanghai: Prostitution et sexualité en Chine aux XIXe-XXe siècles. Paris: CNRS Éditions.

Hershatter, Gail. 1997. Dangerous Pleasures: Prostitution and Modernity in Twentieth-Century Shanghai. Berkeley: University of California Press. 
Hu Shi. 1997 (originally 1925). "Hu Shi xu.” In Han Bangqing, 1997: 1-18.

Hu Ying. 1997. "Re-Configuring Nei/Wai: Writing the Woman Traveler in the Late Qing." Late Imperial China 18.1: 72-99.

Li Wai-yee. 1997. “The Late Ming Courtesan: Invention of a Cultural Ideal.” In Widmer and Chang, ed., 46-73.

Liu Bannong. 1997 (originally 1925). “Du Haishanghua liezhuan.” In Han Bangqing, 1997: 19-33.

Mann, Susan. 1997. Precious Records: Women in China's Long Eighteenth Century. Stanford: Stanford University Press.

McMahon, Keith. 1995. Misers, Shrews, and Polygamists: Sexuality and MaleFemale Relations in Eighteenth-Century Chinese Fiction. Durham: Duke University Press.

Ropp, Paul. 1997. “Ambiguous Images of Courtesan Culture in Late Imperial China." In Widmer and Chang, ed., 17-45.

Wang, David Der-wei. 1997. Fin-de-siècle Splendor: Repressed Modernities of Late Qing Fiction, 1849-1911. Stanford: Stanford University Press.

Widmer, Ellen and Kang-i Sun Chang, ed. 1997. Writing Women in Late Imperial China. Stanford: Stanford University Press.

Wu Liansheng et al., ed. 1995. Wu fangyan cidian. Beijing: Hanyu da cidian chubanshe.

Wu, Yenna. 1995. The Chinese Virago: A Literary Theme. Cambridge: Harvard University Press.

Wu Weiye. 1922. Meicun jiacangji. Shanghai: Shangwu yinshuguan. In Sibu congkan jibu, 1680-1683.

Yeh, Catherine Vance. 1997. "The Life-style of Four Wenren in Late Qing Shanghai." HJAS 57.2: 419-470.

_. 1998. "Reinventing Ritual: Late Qing Handbooks for Proper Customer Behavior in Shanghai Courtesan Houses." Late Imperial China 19.2: 1-63.

_.2000. "Cong shijiu shiji Shanghai ditu kan dui chengshi weilai dingyi de zhengduozhan.” Zhongguo xueshu 1.3: 88-121.

Yu Huai. 1966. Trans. Howard Levy. A Feast of Mist and Flowers. Yokohama: mimeographed. 
Zamperini, Paola. 1999a. "But I Never Learned to Waltz: The 'Real' and Imagined Education of a Courtesan in the Late Qing." Nan Nü 1.1: 107-144.

_. 1999b. "Lost Bodies: Images and Representations of Prostitution in Late Qing Fiction." Ph.D. Dissertation, University of California at Berkeley.

Zhang Ailing, trans. 1983. Haishanghua. Taibei: Huangguan chubanshe.

Zou Tao. 1993. Haishang chentianying. Nanchang: Baihuazhou wenyi chubanshe. 